\title{
CORRESPONDENCE
}

\section{ON SOME TURKISH ROCKS}

SIR, -I have read with interest the letter by Ager (1) referring to what I may call boulder-beds, block-beds, and breccias of different types. The reader of that letter may well get the impression that our views on the origins of these rocks are confused like the rocks themselves. Let me refer to the Turkish examples first.

(a) Your readers will readily appreciate that many of the rocks mentioned in the first paragraph were described by Bailey and myself (2) in some detail. Although no reference was made to this work we are probably included in the group of "nappe-minded geologists". However, the point here is that a tectonic origin was ascribed to the Ankara mélange.

(b) Although Turkish geologists have considered the Sile occurrences of mixed Cretaceous and Tertiary rocks as of tectonic origin also, I have suggested on a number of occasions in conversation with them that a sedimentary origin would better explain the phenomena. A summary of my views has been published (3).

(c) Reference was made to the joint paper by Tokay and myself on the Cretaceous deposits of the Zonguldak region. There we emphasized the sedimentary-slump nature of the rocks and pointed to the frequency of graded bedding and other features of turbidity currents. It is true that, at the time I read the paper, Migliorini compared the phenomena to those of the Argille scagliose. Since then other Italian geologists have, in conversation, compared the Ankara Mélange to the Argille scagliose. Accordingly the Argille scagliose is compared by the Italian School to both a tectonic mélange and to a sedimentary mixture. Recently Bailey and $I$ have examined many sections of Argille scagliose in Tuscany and Liguria and we continue to be "nappe-minded".

W. J. McCallien.

\section{REFERENCES}

(1) AgER, D. V., 1958. On Some Turkish Sediments. Geol. Mag., xcv, 83.

(2) Bailey, E. B., and MCCallien, W. J., 1950. The Ankara Mélange and the Anatolian Thrust. M.T.A. Publ. No. 40.

1953. Serpentine Lavas, etc. Trans. Roy. Soc. Edinburgh, 1xii, ii, 403.

(3) McCallien, W. J., 1955. La structure de la côte occidentale du Bosphore et de la côte voisine de la Mer Noire. C.R. Somm. Soc. Géol. France, Nos. 5-6, 102.

1957. Some Sedimentary Structures. Publ. Board, Univ. Coll. Ghana (Nelson and Sons, Ltd.).

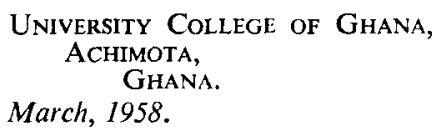

\section{ANTIDUNES AND FLAME STRUCTURES}

SIR,--It was with great interest that I read Lamont's further exposition of his views on the origin of "flame-structures", but I cannot agree with his explanation. It seems that Lamont envisages the development of an eddy of sand and water of sufficient violence to be able to support an overhanging thin film of clay. I cannot believe that such a structure could have more than a momentary existence; it would surely collapse once the eddy ceased. Even if such structures could be preserved, it would be wrong to attribute them to the action of antidunes. Gilbert $(1914$, p. 32) in his original description of antidunes, emphasizes that in them sand grains flow parallel with the bed in the troughs and up and down in the crests; he observes no reversed movement 
and Bucher (1919, p. 165) clearly states that no vortices are involved. Thus the concavo-convex form of the flame-structure is not typical of antidunes. All authors agree that antidunes are symmetric in cross-section, and are "like very flat sine curves" (Blench, T., 1957, p. 8). Recorded wave-lengths and amplitudes are as follows (converted to cms.)

Wave-lengths around $23 \mathrm{cms}$. (Cornish, V., 1899, p. 626)

, ", 450-600 cms., amplitude approx. $80 \mathrm{cms}$. (Pierce, 1916, p. 42)

" " " 60-90 cms., amplitude approx. $15 \mathrm{cms}$. (Gilbert 1914, p. 32)

The figures given by Bucher seem to be an inaccurate conversion to metric units of those given by Gilbert. Many of the structures described by Lamont far exceed in relative amplitude anything yet described for modern antidunes. It is possible that the movement of the sand in the antidunes, since it does not appear to be by saltation, might generate movement in the partially consolidated layers below. This movement is known to occur below the larger "progressive sand-waves" described by Bucher. This dragging might produce flame-structures in an alternation of sand and clay, and it seems to me the only way in which antidunes could produce a flame structure.

Lamont attributes his antidunes to the action of vortices on a layer of sediment. Vortices appear to be generated on the bed of a modern stream only at water velocities associated with the formation of current-ripples i.e. at slower speeds than those which form antidunes (Bucher, W. H., 1919). In fact, Lamont's term "slow antidunes" seems self-contradictory, if by "slow" he implies movement of the order of 8-10 cms. pr. sec., as his introductory remarks suggest. If vortices are responsibie for flame-structures, then they are more likely to be "dune-forming " than " antidune-forming".

Whilst it may be true that some flame-structures originated by vortical movement during deposition, in most cases a post-depositional origin is indicated as is clearly shown by Kelling and Walton (1957,p. 481 et seq.) Nevertheless I feel that the latter authors do not attach sufficient importance to "flow" (i.e. horizontal movement of sediment) as opposed to "loading " (i.e. vertical movement). Whilst agreeing that pure loading may explain many features, it is difficult to believe that flame-structures with a consistent direction of overturn do not reflect some horizontal movement of sediment. Whether such features should be called load casts or flow casts is arguable, since most examples involve movement which is neither purely horizontal nor purely vertical. Shrock's term "flow-cast" has priority of date (which commends it to the palaeontologist) whilst Kuenen's "load-cast" is now more commonly used. Nevertheless, there remains a category of structures which may have been initiated by flow of the overlying sediment, such as the structures I described (Prentice, 1956) from North Devon, and the examples of Group II of Kelling and Walton (1957, p. 485). The evidence presented by the latter authors for the origin of these structures as load-cast ripple-marks is not as yet convincing, and I look forward with interest to the promised expansion of these views. If we are to adhere to a genetic nomenclature for these sedimentary structures, it is important that the processes of formation should be properly understood before the nomenclature is applied.

\section{REFERENCES}

BLENCH, T., 1957. Regime behaviour of canals and rivers. London, $138 \mathrm{pp.}$ BUCHER, W. H., 1919. On ripples and related sedimentary surface forms and their palaeogeographic interpretation. Am. Journ. Sci., xcvii, $149-210,241-269$.

Cornish, V., 1899. On kumatology. Geogr. Journ., xiii, 624-8.

GilberT, G. K., 1914. The transportation of debris by running water. U.S. Geol. Surv. Prof. Paper No. 86.

Kelling, G. and E. K. WALton, 1957 . Load-cast structures; their relationship to Upper surface structures and their mode of formation. Geol. Mag., xciv 481-490. 
LAmont, A., 1957. Slow anti-dunes and flow marks. Geol. Mag., xciv $472-480$.

Pierce, R. C., 1916. The measurement of silt-laden streams. U.S. Geol. Surv. Water Supply Paper 400-C, 41-3.

Prentice, J. E., 1956. The interpretation of flow-markings and load-casts. Geol. Mag., xciii, 393-400.

J. E. Prentice.

UNIVERSITY OF LONDON,

King'S COLLEGT,

StRAND, W.C.2.

4th Februarv, 1958.

\section{LOAD-CASTS AND FLAME STRUCTURES}

SIR, - At the risk of over-inflating an already dangerously distended literature on load-casts and related penecontemporaneous sedimentary structures, may I add a comment to the interesting account of Kelling and Walton in the November-December issue of the Geological Magazine for 1957. It is unusual to conceive that ripple-mark should develop in muddy sediments, and if it did its presence would be revealed by current bedding, at least for transverse and interference-ripples. I have examined hundreds of perfectly displayed load-casts, and although current bedding is sometimes to be seen in the overlying sandstones, $I$ have never seen it in the argillaceous under-beds. The authors have, however, reached a conclusion regarding the origination of mudstone injections from ripple crests that in all other ways agrees with my own, originally published many years ago (Roy. Soc. Vict., Vol. 53, 1941, pp. 167-91) and referred to (with illustrations) more recently in Outlines of Structural Geology (London, 1953, pp. 11-13) including diapirism, analogy with salt domes (based in 1941 on Nettleton's experiments), and the suggestion that asymmetry of "flame" structures may reflect slight differential movements during compaction. In the Victorian examples, however, the ripple mark is actually preserved on a sandstone underlying the injected mudstone, not on the mudstone itself. The notion deriving from the later experiments of Parker and Macdowell that the height of the mud-domes may be controlled by the thickness of superincumbent sand has not escaped the writer, who was perhaps in error on this point in 1941, and it is interesting to note that the "overhang " so characteristic of salt domes is common in mudstone injections, which do in fact approximate to a definite elevation in any one bed (Outlines, fig. 6D, p. 11). The possible influence of differential loading (even after deposition amounting only to something of the order of an inch of sand) must not, however, be overlooked. True pseudonodules of the type erected by Marcar and Antun (Bull. Soc. géol. Belg., vol. 73, 1950, pp. 121-49) most probably represent isolated or nearly isolated sand ripples with current-bedding (Outlines, fig. 6E) which sank into the soft mud developing flanges analogous with those of australites, due to fluid-dynamic moulding as they sank. Finally, I personally cannot resist the force of Sorby's beautiful illustrations and logic in ascribing flame structures and other mudstone injections in the Langdale slates, without any underlying ripples, to the breaking up of a deposit that was in a " creamy semi-liquid condition" (Quart. Journ. Geol. Soc., vol. 64, pp. 171-233), a conclusion that agrees well enough with the concept, unknown to him, of turbidity current deposition and with experiments with oil films on water, which faithfully reproduce flame structures by differential flow. According to this notion asymmetrical flame structures are Helmholtz waves modified by the rheid properties of the materials so that the "anticlines" become pointed and inject the sandstone. The occurrence of examples with an amplitude of 6 to 10 feet in basalt resting on carbonaceous clay at Berwick, Victoria, is particularly interesting from this point of view. With sediments believed to be deposited by turbidity 